\title{
Organising distance learning for Master's in Pharmacy in Ukraine during COVID-19 quarantine
}

\author{
I. Nizhenkovska, O. Kuznetsova, V. Narokha* \\ Bogomolets National Medical University, Pharmaceutical Faculty, Ukraine
}

\author{
Keywords \\ Teaching Methods \\ Assessment \\ COVID-19 \\ Ukraine \\ ${ }^{*}$ Corresponding author: \\ v.narokha@ukr.net
}

\begin{abstract}
Summary: This article analyses the effectiveness of distance learning technologies for students in the pharmaceutical departments of the universities in Ukraine during quarantine due to the COVID-19 coronavirus pandemic. It is based on a study of distance learning implementation at the Department of Pharmaceutical, Biological and Toxicological Chemistry of the Bogomolets National Medical University (NMU) of the Ministry of Health of Ukraine using the NEURON education and information platform. The results of the online survey of the students of the Pharmaceutical Faculty of the Bogomolets NMU showed that online testing (99.1\%), e-mail (91.2\%) and text chats $(88.5 \%)$ were the most commonly used distance learning technologies. The authors of the study conclude that it is necessary to develop specific distance learning technologies in medical (pharmaceutical) higher education institutions in order to increase course quality, competitiveness, flexibility and attractiveness.
\end{abstract}

\section{Background and Context}

Following Resolution No. 211 of the Cabinet of Ministers of Ukraine dated 11th March 2020 'On Prevention of the Spread of the COVID-19 Coronavirus in Ukraine', quarantine was introduced in the territory of Ukraine, which made traditional teaching impossible (Government Portal Ukraine, 2020). The Ministry of Education and Science of Ukraine (MES) developed several regulatory documents with the aim of organising educational processes during quarantine, including Order No. 406 dated 16th March 2020 'On Organisational Measures to Prevent the Spread of the COVID-19' (MES, 2020). The Order obliged the heads of higher pharmaceutical education institutions to develop a quarantine work plan using distance learning, and to provide a flexible work schedule for professors.

In 2000, the 'Concept for the Development of Distance Education in Ukraine' was approved where distance learning was defined as: 'a form of organisation and implementation of the educational process, which participants carry out educational interactions principally and mainly extraterritorially [.e. at a distance, without direct face-to-face educational interactions, or when the participants are geographically beyond possible direct educational interaction, etc]'

(Educational Portal, 2000)

At present, there are several revised regulatory documents that emphasise the importance of distance learning in Ukraine:

- Order No. 293 'On the Foundation of the Ukrainian Centre for Distance Education' (MES, 2000)

- Order No. 761 'On approval of Amendments to the Regulation on Distance Learning' (MES, 2015)

- Law of Ukraine 'On Education' (Parliament of Ukraine, 2020a)

- Law of Ukraine 'On Higher Education (Parliament of Ukraine, 2020b) 


\section{Educational Description}

The Moodle electronic monitoring platform, known as the Learning Management System (LMS), or the virtual learning environment (VLE) are widely used for distance learning in pharmacy departments of higher educational institutions in Ukraine. In addition, web services are also used; Google Classroom is useful for educational institutions; Google Meet, Zoom and Skype for video conferences; and Viber, Telegram messengers, email or telephone for individual consultations. Online learning has offered an interactive approach to communication between professors and students, aimed at developing specific professional competencies in students of the Master of Pharmacy programme.

At the Department of Pharmaceutical, Biological and Toxicological Chemistry of the Bogomolets National Medical University (NMU) of the Ministry of Health of Ukraine, distance learning was implemented using the NEURON educational and information platform. It allowed students to communicate with their professors, receive online advice, and monitored students' site traffic. A vast array of materials were made available on the NEURON platform, including educational and methodological materials such as video clips and lecture presentations; methodological recommendations for the preparation for practical and seminar classes; additional materials for the preparation for practical classes (tables, diagrams and schedules); a list of recommended readings; hyperlinks with external online resources and search engines; and individual assignments for students, etc.

Using the resources on the NEURON platform, the professors of the Faculty of Pharmacy conducted practical classes and seminars with students, and organised intermediate and final assessments of students' knowledge of the disciplines covered. Based on the results of the students' written assignments, the professors gave grades to the students in an electronic journal and made comments using a general department email address.

The NEURON platform interface was convenient for the students and adaptable to any device, it allowed for viewing of the uploaded materials or testing at a convenient time and place. The NEURON educational and information platform is used to prepare Year 3 students for a licensed Unified State Qualification Exam (USQE) for the applicants for Master's degrees in Pharmacy. The USQE included the integrated test 'KROK1. Pharmacy' and an English exam on professional level knowledge across eight academic disciplines: analytical, physical, colloidal, organic and biological chemistry, pathophysiology, microbiology, botany, and pharmacology.

In an online survey of students from the Faculty of Pharmacy, conducted after the end of the quarantine period (at the end of the 2019-2020 academic year), students mentioned online testing $(99.1 \%)$, email $(91.2 \%)$, text chats $(88.5 \%)$, video lectures $(55.0 \%)$ and interactive exercises $(22.3 \%)$ among the technologies that were commonly used during distance learning at the Department of Pharmaceutical, Biological and Toxicological Chemistry of the Bogomolets NMU.

\section{Outcomes and Recommendations}

Intermediate results of this active transition of the pharmaceutical faculties within Ukrainian universities to distance learning show that the self-discipline and selforganisation of the students (i.e. those who can independently choose a curriculum, draw up an individual class schedule, study anywhere with a device connected to the Internet and contact professors online) are very important aspects of this form of education.

Although it is still behind European educational systems, the last decade has seen positive changes to the systems in Ukraine. Despite the difficulties and problems in the educational environment that arose during the transition to distance learning in Ukrainian institutions, it should be noted that the development of distance learning technologies in Ukraine will make pharmaceutical education better, more competitive, more flexible and more attractive to students.

The future of higher pharmaceutical education in Ukraine depends on how quickly some issues of distance support will be resolved. These issues include the creation of software products such as online course resources for distance learning platforms; integration with cloud technologies; online student identification standards; the issue of academic load for professors; advanced training for professors; and professional burnout amongst others.

Distance learning is a prerequisite and a condition for the academic mobility of both students and professors, which will assist with the integration of the Ukranian system of pharmaceutical education into the European educational environment.

\section{References}

Educational Portal. (2000). Available at: http://www.osvita.org.ua/ distance/pravo/00.html

Government Portal Ukraine. (2020). Available at: https:// www.kmu.gov.ua/npas/pro-zapobigannya-poshim110320rennyuna-teritoriyi-ukrayini-koronavirusu-covid-19

MES [Ministry of Education and Science of Ukraine]. (2000). Available at: https://osvita.ua/legislation/Dist osv/3137/

MES [Ministry of Education and Science of Ukraine]. (2015). Available at: https://zakon.rada.gov.ua/laws/show/z0923-15\#Text

MES [Ministry of Education and Science]. (2020). Available at: https://mon.gov.ua/ua/npa/pro-organizacijni-zahodi-dlyazapobigannya-poshirennyu-koronavirusu-s-ovid-19

Parliament of Ukraine. (2020a). Legislation of Ukraine. On Education. Available at: https://zakon.rada.gov.ua/laws/show/2145-19\#Text

Parliament of Ukraine. (2020b). Legislation of Ukraine. On Higher Education. Available at: https://zakon.rada.gov.ua/laws/show/ 1556-18\#Text 